\title{
KEBERADAAN EKTOPARASIT PADA BUDIDAYA IKAN TOMAN (Channa micropeltes L) DI KECAMATAN JEJAWI KABUPATEN OGAN KOMERING ILIR
}

\section{Existence Of Ectoparacite In Toman Fish (Channa micropeltes L) Cultivation In Jejawi District, Ogan Komering District Ilir}

\author{
Yudha Wira Pratama ${ }^{1}$, Marmaini $^{2}$, Dian Mutiara ${ }^{2 *}$ \\ ${ }^{1}$ Prodi Ilmu Perikanan, Fakultas Perikanan dan Kelautan Universitas PGRI Palembang \\ ${ }^{2}$ Prodi Biologi, Fakultas Sains dan Teknologi, Universitas PGRI Palembang \\ * Corresponding author: dihartaa@gmail.com
}

\begin{abstract}
ABSTRAK
Tujuan penelitian ini adalah untuk mengetahui jenis-jenis ektoparasit, indeks prevalensi dan intensitas tingkat serangan ektoparasit pada ikan toman (Channa micropeltes L) yang dibudidaya di Sungai Komering Kecamatan Jejawi, Kabupaten Ogan Komering Ilir. Penelitian dilaksanakan pada bulan November 2016 hingga Januari 2017. Identifikasi ektoparasit pada ikan toman dilakukan di Balai Karantina Ikan, Pengendalian Mutu dan Keamanan Hasil Perikanan Kelas II Palembang. Dari hasil pengamatan secara mikroskopis ditemukan jenis ektoparasit yang terdiri dari Tricodina sp, Dactylogyrus sp dan Argulus sp. Nilai indeks prevelensi tertinggi yaitu 50\% dan intensitas serangan parasit tertinggi yaitu $67,5 \%$. Nilai tersebut mengindikasikan bahwa kriteria prevalensi dan intensitas serangan termasuk kategori infeksi yang sangat sering dengan tingkat serangan sangat sering.
\end{abstract}

Kata Kunci: Ektoparasit, Ikan Toman (Channa micropeltes L), Indeks Prevelensi, Intensitas Serangan.

\begin{abstract}
The purpose of this study was to determine the types of ectoparasites, prevalence index and intensity of ectoparasite attack on toman (Channa micropeltes L) cultivated in Komering River, Jejawi District, Ogan Komering Ilir Regency. The research was conducted from November 2016 to January 2017. Identification of ectoparasites in toman fish was carried out at the Fish Quarantine Center, Quality Control and Safety of Class II Fishery Products in Palembang. From the results of microscopic observations found ectoparasites consisting of Tricodina sp, Dactylogyrus sp and Argulus sp. The highest prevalence index value was $50 \%$ and the highest parasite attack intensity was $67.5 \%$. This value indicates that the criteria for prevalence and intensity of attacks include the category of very frequent infections with very frequent attacks.
\end{abstract}

Keyword : Ectoparasites, Toman Fish (Channa micropeltes L), Prevalence Index, Attack Intensity. 


\section{PENDAHULUAN}

Ikan toman (Channa microptles L.) merupakan salah satu jenis ikan dari genus Channa yang sering dikonsumsi oleh masyarakat karena memiliki cita rasa yang enak, gurih, dan lezat (Jatilaksono, 2007 dalam Umara, 2014). Dalam budidaya ikan, penyakit merupakan salah satu faktor utama penyebab kematian pada ikan, terutama pada saat stadia benih. Menurut Sharma, et al (2012) dalam Andriyanto et al, (2020), penyakit pada ikan dapat disebabkan oleh patogen yang terbawa oleh ikan carrier sehingga menginfeksi ikan yang sehat. Patogen yang dapat menyebabkan penyakit ikan terdiri atas virus, bakteri, parasit dan jamur.

Menurut Sindermann (1990) dalam Umara et al (2014), keberadaan parasit pada ikan akan berdampak pada pengurangan konsumsi, penurunan kualitas pada usaha budidaya, penurunan bobot badan ikan konsumsi dan penolakan oleh konsumen akibat adanya morfologi atau bentuk tubuh ikan yang abnormal.

Terbatasnya informasi mengenai parasit yang menginfeksi ikan toman menyebabkan permasalahan dalam penanganan dan pengendalian penyakit. Untuk itu perlu dilakukan penelitian yang bertujuan untuk mengidentifikasi jenis parasit yang menyebabkan penyakit pada ikan toman beserta nilai indeks prevalensi dan intensitas serangan untuk menentukan metode yang tepat dalam rangka penanggulangan penyakit potensial pada ikan toman.

\section{METODE PENELITIAN \\ Waktu dan Tempat}

Penelitian ini dilaksanakan pada bulan November 2016 hingga Januari 2017, berlokasi di Sungai Komering Kecamatan Jejawi Kabupaten Ogan Komering Ilir.

Identifikasi ektoparasit ikan toman dilakukan di Balai Karantina Ikan,
Pengendalian Mutu Dan Keamanan Hasil Perikanan Kelas II Palembang.

\section{Alat dan Bahan}

Alat yang digunakan dalam penelitian ini meliputi kaca preparat, kaca penutup, mikroskop, timbangan analitik, jangka sorong, alat bedah, cawan petri, pipet tetes, kamera digital, serok, baskom, Tissue, thermometer, $\mathrm{pH}$ meter, DO meter, pipet volumetric, erlemeyer. Sedangkan bahan yang digunakan meliputi ikan toman, akuades, garam fisiologis $(\mathrm{NaCl} 0,9 \%)$, sulfanilamide, N-1-Napthyl ethykene diamine dihydrochloride (NED), larutan standar nitrit $\left(\mathrm{NaNO}_{2}\right) 1 \mathrm{mg} / \mathrm{1}^{-1}$, kertas saring whatman no.42, indikator phenolpthalein, natrium karbonat $\left(\mathrm{Na}_{2} \mathrm{CO}_{3}\right)$ $0,0454 \mathrm{~N}$.

\section{Metode Penelitian}

Penelitian ini dilakukan dengan menggunakan metode purposive sampling, berdasarkan rona lingkungannya dengan 3 stasiun pengambilan sampling (Gambar 1), yaitu:

Stasiun 1: Sungai Komering di desa Bubusan Kecamatan Jejawi Kabupaten Ogan Komering Ilir. Faktor lingkungan air yang mengalir, tidak ada tanaman air disekitar wadah budidaya.

Stasiun 2: Sungai Komering di desa Muara Batun Kecamatan Jejawi Kabupaten Ogan Komering Ilir. Faktor lingkungan air tidak mengailir, warna air yang agak keruh serta banyaknya tanaman air disekitar wadah budidaya.

Stasiun 3: Sungai Komering di desa Talang Cempedak Kecamatan Jejawi Kabupaten Ogan Komering Ilir. Faktor lingkkungan air yang tidak mengalir, kegiatan masyarakat penambangan pasir dan banyaknya tanaman air di sekitar wadah budidaya. 


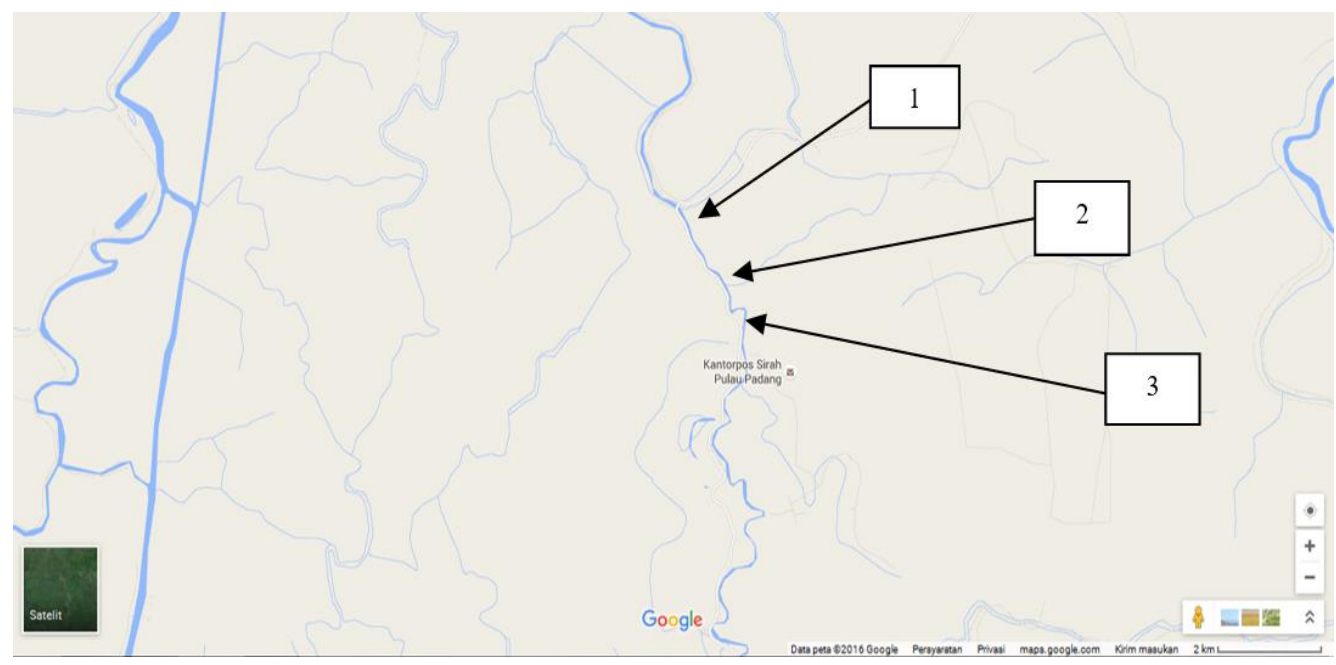

Gambar 1. Lokasi Pengambilan Sampel Ikan Toman

(Sumber : Google Maps, 2017)

\section{Parameter yang Diamati}

Identifikasi ektoparasit

Ektoparasit diidentifikasi dengan menggunakan mikroskop cahaya yang dilengkapi dengan kamera. Mikroskop yang digunakan yaitu jenis mikroskop kamera koneksi komputer sehingga parasit yang ditemukan dapat langsung di dokumentasikan untuk proses identifikasi. Identifikasi parasit yang ditemukan mengacu pada buku-buku petunjuk identifikasi Kabata (1985) dan Fernando (1972).

\section{Indeks Prevalensi}

Tingkat prevalensi ektoparasit dihitung dengan menggunakan rumus Fernando, et al. (1972), sebagai berikut :

Prevalensi $=$ $\frac{\text { Jumlah ikan sampel yang terserang parasit }}{\text { Jumlah ikan sampel yang diperiksa }} \times 100 \%$

\section{Intensitas Tingkat Serangan}

Intensitas tingkat serangan ektoparasit dihitung dengan menggunakan rumus Kabata (1985), sebagai berikut:

Intensitas $=\frac{\text { Jumlah parasityangditemukan }}{\text { Jumlah } \text { ikanyangterinpeksi }}$

\section{Kualitas Air}

Parameter kualitas air yang diamati pada penelitian ini meliputi suhu, $\mathrm{pH}$, Amoniak.

\section{HASIL DAN PEMBAHASAN}

Hasil pengamatan secara mikroskopis di Balai Karantina Ikan, Pengendalian Mutu dan Keamanan Hasil Perikanan (BKIPM) kelas II Palembang tentang keberadaan ektoparasit pada ikan toman (Channa microptles L.), di Kecamatan Jejawi Kabupaten Ogan Komering Ilir, dapat dikelompokan menjadi tiga filum yaitu Protozoa, Plathyhelminthes, dan Arthropoda, sedangkan jumlah spesies parasit yang ditemukan terdiri dari Tricodina sp, Dactylogyrus sp dan Argulus sp. Hasil identifikasi jenis ektoparasit dan daerah penyerangan parasit dapat dilihat pada Tabel 1 dan Gambar 1 berikut ini. 
Tabel 1. Hasil Identifikasi Ektoparasit dan Daerah Penyerangan

\begin{tabular}{|c|c|c|c|c|c|}
\hline \multirow{2}{*}{ No } & \multirow{2}{*}{ Uraian } & & \multicolumn{3}{|c|}{ Spesies parasit } \\
\hline & & & Tricodina sp. & Dactylogyrus sp. & Argulus sp. \\
\hline 1 & Filum & & Protozoa & Plathyhelminthes & Arthropoda \\
\hline 2 & Kelas & & Ciliata & Peritricia & Crustacea \\
\hline 3 & Genus & & Trichodina & Dactylogyrus & Argulus \\
\hline \multirow[t]{2}{*}{4} & Organ & Insang & + & + & - \\
\hline & & lendir* & + & + & + \\
\hline
\end{tabular}

$\begin{aligned} \text { Keterangan }+ & =\text { terinfeksi } \\ - & =\text { tidak terinfeksi } \\ * & =\text { permukaan luar tubuh ikan }\end{aligned}$

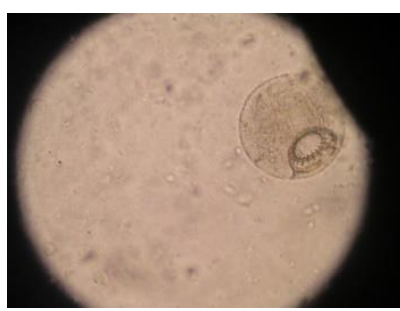

Trichodina sp.

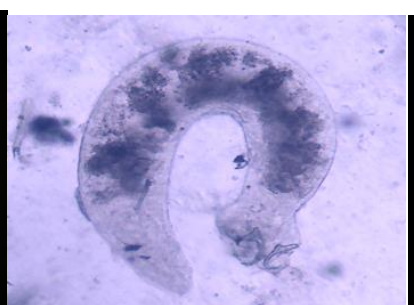

Dactylogyrus sp.

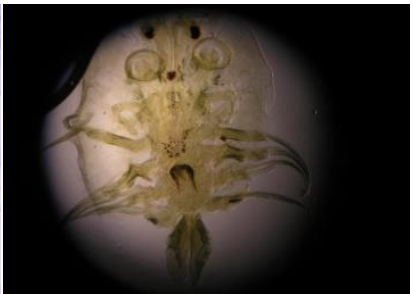

Argulus sp.

Gambar 1. Jenis Ektoparasit yang ditemukan pada Ikan Toman (Sumber : Dokumentasi Pribadi, 2017)

Dari hasil identifikasi terhadap ikan toman, ditemukan ektoparasit Tricodina sp dan Dactylogyrus sp menginfeksi bagian permukaan lendir dan insang sedangkan Argulus sp menginfeksi bagian permukaan lender. Berdasarkan dari pengamatan, ciri umum parasite Tricodina $\mathrm{sp}$ adalah memiliki bentuk tubuh pipih dan terdapat silia pada tubuhnya. Hal ini sesuai dengan pendapat Umara (2014), yang menyatakan bahwa ektoparasit Trichodina spp. memiliki bentuk tubuh seperti piring, memiliki silia di sekeliling tubuhnya, dan bergerak menyamping dengan silianya sehingga terlihat seperti berputar-putar. Terdapat radial pin yang melingkar melindungi dentikel, blade yang berbentuk mata pisau, dan thorn yang meruncing dari dentikel ke arah tengah trichidinid. Sedangkan ciri umum parasite Dactylogyrus sp berdasarkan pengamatan memiliki tubuh seperti pengait. Hal ini sesuai pendapat Yuli (2017) yang menyatakan bahwa ektoparasit Dactylogyrus sp merupakan cacing yang berbentuk seperti jangkar atau pengait, habitat hidupnya berada di insang ikan dan seluruh siklus hidupnya berada di insang ikan. Untuk ektoparasit Argulus sp, berdasarkan pengamatan Argulus sp terdiri dari kepala, kepala badan dan badan. Hal ini sesuai dengan pendapat Kabata (1985) dalam Ode (2012) yang menyatakan bahwa Argulus sp memiliki tiga bagian tubuh yaitu cephalothorax, thorax dan abdomen. Pada cephalothorax terdapat dua pasang maxilla, dimana maxilla pertama termodifikasi menjadi sucker atau alat penghisap dan pada thorax terdapat 3 segmen yang membawa sepasang kaki untuk berenang. Sepasang kaki renang yang keempat berada diantara abdomen dan thorax.

Nilai indeks prevalensi dan intensitas tingkat serangan ektoparasit yang ditemukan pada stasiun 1 (Bubusan), stasiun 2 (Muara Batun) dan stasiun 3 (Talang Cempedak) disajikan pada Gambar 2 dan Gambar 3 berikut ini. 


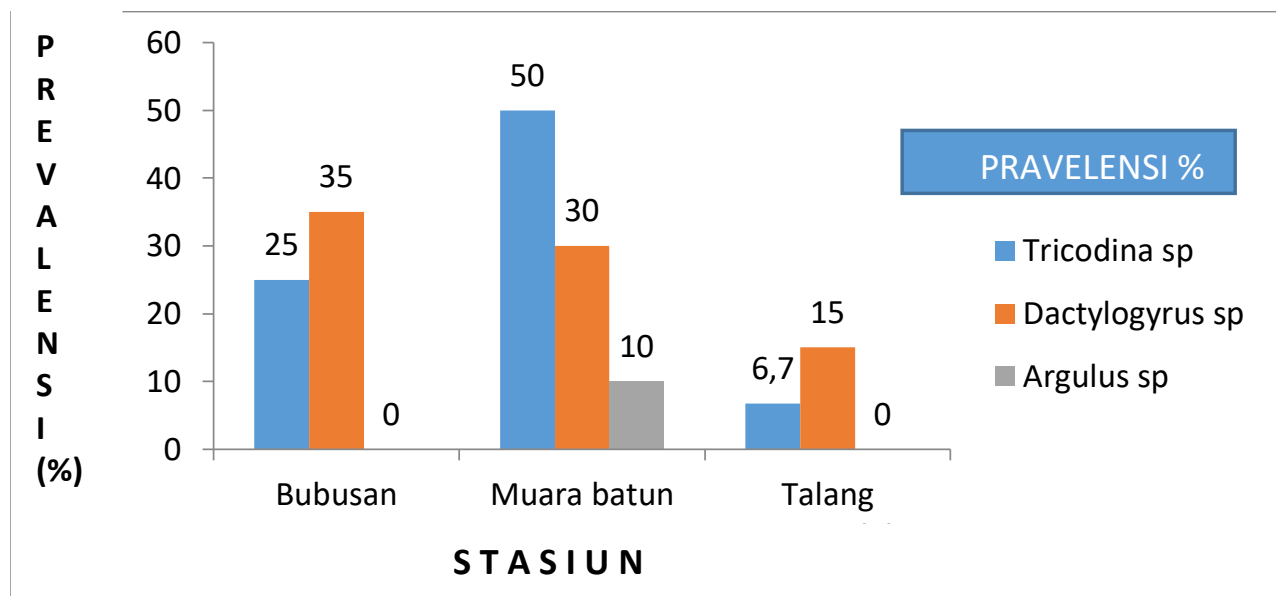

Gambar 2. Indeks Prevelensi rata-rata dengan tiap jenis ektoparasit pada budidaya ikan toman di Kecamatan Jejawi Kabupaten Ogan Komering Ilir.

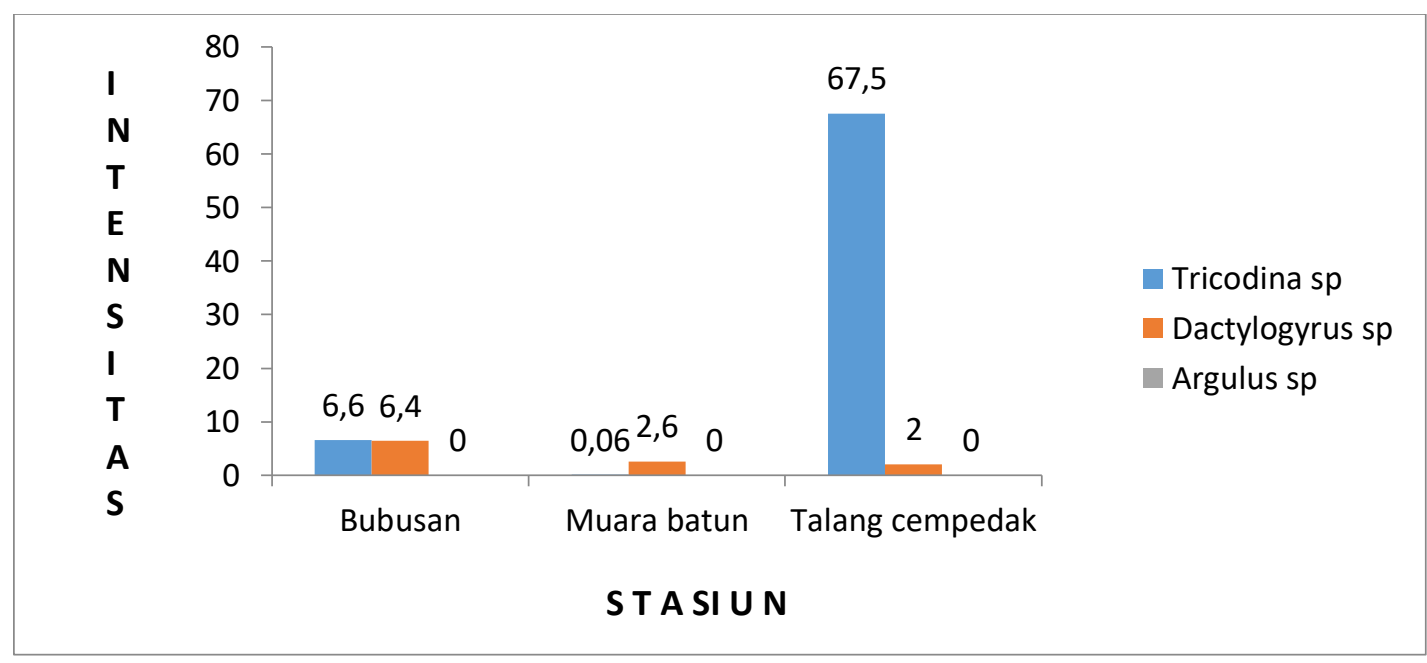

Gambar 3. Intensitas Serangan rata-rata tiap jenis ektoparasit pada budidaya ikan toman di Kecamatan Jejawi Kabupaten Ogan Komering Ilir. 
Berdasarkan pada Gambar 2 dan Gambar 3 diketahui bahwa nilai indeks prevelensi dan intensitas serangan ektoparasit yang menginfeksi ikan toman berkisar antara 0\% hingga 50\% dan 0\% hingga $67,5 \%$. Prevalensi dan intensitas serangan Tricodina sp merupakan yang tertinggi dibandingkan dengan parasite lainnya. Tingginya nilai parasite Tricodina sp diduga karena parasit ini mudah beradaptasi dengan tubuh inangnya, khususnya pada tubuh bagian luar. Hal ini diperkuat oleh Singkoh (2012) dalam Andriyanto et al (2020) yang menyebutkan bahwa parasit Trichodina sp lebih banyak ditemukan dikarenakan parasit tersebut lebih menyukai bagian eksternal tubuh ikan (ektoparasit) dibandingkan bagian internal (endoparasit). Prevalensi parasit yang menginfeksi ikan toman tertinggi hingga terendah yaitu Trichodina sp., Dactylogyrus sp., dan Argulus sp. Jumlah parasite yang ditemukan pada budidaya ikan toman di sungai komering ini lebih sedikit dibandingkan hasil penelitian yang dilakukan Andriyanto et al
(2020) sebanyak 7 spesies yang terdiri dari Trichodina sp., Ichthyophthirius multifiliis, Vorticella sp., Acanthochepalus sp., Henneguya sp., Oodinium sp., dan Dactylogyrus sp. Noble dan Noble (1989) dalam Umara et al (2014) menyatakan bahwa ikan yang menghabiskan seluruh siklus hidupnya hanya di satu tipe perairan akan memiliki parasit lebih sedikit daripada ikan yang berpindah-pindah. Ikan-ikan yang dipelihara terutama dalam akuarium, intensitas dan prevalensi parasitnya cenderung berfluktuasi sesuai dengan pengelolaan kesehatan yang diterapkan dalam kegiatan budidaya. Berdasarkan kriteria prevalensi dan intensitas serangan, nilai infeksi parasite tergolong dalam infeksi yang sangat sering dengan tingkat serangan sangat sering.

Pengukuran parameter kualitas air pada setiap stasiun pengambilan sampel ikan toman (Channa micropeltes. L) disajikan pada Tabel 2 berikut ini.

Tabel 2. Data nilai rata rata parameter kualitas air

\begin{tabular}{lccc}
\hline Parameter & \multicolumn{3}{c}{ Hasil kualitas air } \\
\cline { 2 - 4 } Kualitas air & Stasiun 1 & Stasiun 2 & Stasiun 3 \\
Suhu $\left({ }^{0} \mathrm{C}\right)$ & 25 & 29 & 30 \\
pH & 5.1 & 5.3 & 6.1 \\
Amonia $(\mathrm{mg} / \mathrm{L})$ & 0.12 & 0.16 & 0.18 \\
\hline
\end{tabular}

Dari Tabel 2 diperoleh kisaran nilai suhu pada ke 3 (tiga) stasiun adalah sebesar $25^{\circ} \mathrm{C}$ (stasiun 1$), 29^{\circ} \mathrm{C}$ (stasiun 2 ), dan $30^{\circ} \mathrm{C}$ (stasiun 3). Diduga nilai tersebut merupakan suhu yang tergolong optimal untuk budidaya ikan toman. Hal ini sesuai dengan pendapat Makmur (2003) dalam Candra (2018), yang menyatakan bahwa suhu air yang optimal bagi perkembangan hidup ikan toman berkisar antara $26,5^{\circ} \mathrm{C}$ hingga $31,5^{\circ} \mathrm{C}$. Nilai $\mathrm{pH}$ pada stasiun 1 (Desa Bubusan) sebesar 5,1, stasiun 2 (Desa Muara Batun) 5,3 dan stasiun 3 (Desa Talang Cempedak) sebesar 6,1. Nilai $\mathrm{pH}$ air tersebut diduga masih dalam 
kisaran optimum untuk mendukung kehidupan ikan toman ( Channa micropeltes L). Menurut Muflikhah et al (2008) dalam Sofian et al (2019), nilai pH yang dapat di toleransi ikan dari genus Channa yaitu 4 hingga 9. Pengukuran amonia pada Stasiun I desa Bubusan sebesar 0,12 mg/l, Stasiun II desa Muara Batun sebesar 0,16 mg/l, Stasiun III desa Talang Cempedak sebesar $0,18 \mathrm{mg} / \mathrm{l}$. Kisaran tersebut melebihi batas toleransi untuk kegiatan budidaya ikan. Hal ini sesuai dengan PP RI No. 82 Tahun 2001 tentang Pengelolaan Kualitas Air dan Pengendalian Pencemaran Air, yang dijelaskan bahwa kandungan amoniak untuk kegiatan perikanan adalah $<0.02 \mathrm{mg} / \mathrm{L}$. Tingginya nilai amonia diduga karena adanya aktifitas penduduk dan kegiatan budidaya diperairan tersebut. Hal ini sesuai dengan pendapat Ramadhan (2020); Haris (2019); Haris (2018) yang menyatakan bahwa amoniak dalam perairan berasal dari bahanbahan organik dan hasil eksresi metabolisme ikan melalui ginjal dan jaringan insang, selain itu amoniak yang terdapat dalam keramba, tambak atau perairan dapat terbentuk sebagai hasil dari proses dekomposisi protein yang berasal dari sisa pakan atau plankton yang mati.

\section{SIMPULAN}

Simpulan yang diperoleh pada penelitian ini adalah ditemukannya jenis ektoparasit pada ikan toman yang di budidaya di Kecamatan Jejawi Kabupaten Ogan Komering Ilir yang terdiri dari Trichodina sp, Dactylogyrus sp dan Argulus sp. Nilai indeks prevelensi tertinggi yaitu $50 \%$ dan intensitas serangan parasit tertinggi yaitu $67,5 \%$. Nilai tersebut mengindikasikan bahwa kriteria prevalensi dan intensitas serangan termasuk kategori infeksi yang sangat sering dengan tingkat serangan sangat sering.

\section{DAFTAR PUSTAKA}

Andriyanto, S., Novita, H., Lusiastuti, A. M., dan Taukhid, T. 2020. Identifikasi Bakteri Patogen Dan Parasit Penyebab Penyakit Pada Ikan Toman (Channa micropeltes). Media Akuakultur. Vol.15 (1) : 39-46.

Candra, A.M. 2018. Pertumbuhan Dan Kelulushidupan Benih Ikan Toman (Channa Micropeltes) Yang Diberi Pakan Tubifex Sp Dengan Jumlah Berbeda. Jurnal JOMFAPERIKA. Vol.5(2) : 1-11

Fernando, C. H., Gussev, A. V., Hanek, G., Furtando, J.I., dan Kakonge, S.A. 1972. Methods for the Study of Freshwater Fish Parasites. University of Waterloo. Canada. Biology Series.

Haris, R.B.K., dan Yusanti, I.A. 2018. Studi Parameter Fisika Kimia Air Untuk Keramba Jaring Apung Di Kecamatan Sirah Pulau Padang Kabupaten Ogan Komering Ilir Provinsi Sumatera Selatan. Jurnal Ilmu-ilmu Perikanan dan Budidaya Perairan. Vol.14(2). Hlm : 57-62. DOI: http://dx.doi.org/10.31851/jip bp.v13i2.2434

Haris, R.B.K., dan Yusanti, I.A. 2019. Analisis Kesesuaian Perairan Untuk Keramba Jaring Apung Di Kecamatan Sirah Pulau Padang Kabupaten Ogan Komering Ilir Provinsi Sumatera Selatan. Jurnal Lahan Suboptimal. Vol. 8 (1). Hlm : 20-30. DOI: https://doi.org/10.33230/JLSO .8 .1 .2019 .356

Kabata, Z. 1985. Parasited and Disease of Fish Culture in The Tropics. Taylor and Francis. London and Philadelphia.

Ode, I. 2012. Argulus Ektoparasit Pada Ikan. Jurnal Bimafika. Vol.4(1) : 413 - 416 
Ramadhan, R., dan Yusanti, I.A. 2020. Studi Parameter Studi Kadar Nitrat Dan Fosfat Perairan Rawa Banjiran Desa Sedang Kecamatan Suak Tapeh Kabupaten Banyuasin. Jurnal Ilmuilmu Perikanan dan Budidaya Perairan. Vol 15(1) : 37-41. DOI: http://dx.doi.org/10.31851/jipbp.v15i 1.4407

Sofian, S., Anwar, S., dan Saputra, M. 2019. Kinerja Pertumbuhan Ikan Gabus (Channa striata) Dengan Suplementasi Astaxanthin Pada Level Berbeda. Jurnal Akuakultur Rawa Indonesia. Vol. 7(2) : $77-85$.

Umara, A., Bakri, M., dan Hambal, M. 2014. Identifikasi Parasit Pada Ikan Gabus (Channa striata) Di Desa Meunasah Manyang Lamlhom, Kecamatan Lhoknga Aceh Besar. Jurnal Medika Veterinaria. Vol. 8(2) : 110-113.

Yuli, S., Harris, H., Yusanti, I. A. 2017. Tingkat Serangan Ektoparasit pada Ikan Patin (Pangasius hypopthalmus) yang Dibudidayakan dalam Keramba Jaring Apung di Sungai Musi Palembang. Jurnal Ilmu - ilmu Perikanan dan Budidaya Perairan. Vol.12(2) : 50-58. DOI : http://dx.doi.org/10.31851/jipbp.v12i 2.1473

Maulana, D. M., Muchlisin, Z. A., dan Sugito, S. 2017. Intensitas dan Prevalensi Parasit Pada Ikan Betok (Anabas testudineus) dari Perairan Umum Daratan Aceh Bagian Utara. Jurnal Ilmiah Mahasiswa Kelautan dan Perikanan. Vol. 2(1) : 1-11. 